\title{
Finite Element Analysis (FEA) and experimental stress analysis in circular perforated plates loaded with concentrated force
}

\author{
Mateusz Marcin Konieczny, Henryk Achtelik, Grzegorz Gasiak \\ University of Technology in Opole, Poland \\ mateuszmarcinkonieczny@wp.pl, h.achtelik@po.edu.pl,g.gasiak@po.edu.pl
}

\begin{abstract}
The paper presents an analysis of an isotropic circular axisymmetric perforated plate loaded with concentrated force $P_{i}$ applied in the geometric center of the plate using finite element software ANSYS. The test plate with diameter $D=300$ $\mathrm{mm}$ has holes arranged at ten different radial spacings. The plate has holes with diameter $d_{1}=3.5 \mathrm{~mm}$ on the first inner circle, and holes on the tenth outside circle have a diameter $d_{10}=20.5 \mathrm{~mm}$. The plate of the above geometry was free supported and loaded with different values of concentrated force. By means of numerical calculations using the finite element method, the coordinates of equivalent (von Mises) stress concentration zones in the perforated plate were determined. These zones were located on the plate bridges between perforation holes. The most hazardous place in the analysed perforated plate is associated with the outer circle, $Z 10$, with the hole radius $d_{1}=3.5 \mathrm{~mm}$ at the circle radius $R_{1}=22.5 \mathrm{~mm}$, where the highest stress concentration occurs. In this zone, the equivalent (von Mises) stress is $\sigma_{\text {red } \max }=416.90 \mathrm{MPa}$ (point with the coordinates $\mathrm{x}, \mathrm{y}, \mathrm{z}[\mathrm{mm}]$, i.e. $\mathrm{P}_{10}[-69.9 ; 72.5$; $0.0]$ ). The results of numerical calculations were verified with experimental results. The differences between the results of numerical calculations of the state of stress and those obtained experimentally did not exceed $31 \%$.
\end{abstract}

KEYWORDS. Circular perforated plate; Concentrated force; Equivalent (von Mises) stress; Numerical calculations; Experimental research

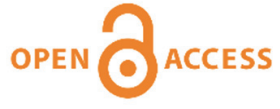

Citation: Konieczny, M. M., Achtelik, H., Gasiak, G., Finite Element Analysis (FEA) and experimental stress analysis in circular perforated plates loaded with concentrated force, Frattura ed Integrità Strutturale, 51 (2020) 164-173.

Received: 06.10.2019

Accepted: 12.11 .2019

Published: 01.01.2020

Copyright: (C2020 This is an open access article under the terms of the CC-BY 4.0, which permits unrestricted use, distribution, and reproduction in any medium, provided the original author and source are credited.

\section{INTRODUCTION}

I $\mathrm{n}$ engineering practice, a plate construction element is often used in which a series of holes are drilled to form a dense, regular mesh. Currently, there are many applications of perforated plates, e.g. in a pressure vessel, chemical apparatus (heat exchanger tube walls) [1-4], oil refineries [5], air units, e.g. construction elements of aircraft and spacecraft, robots, transport containers, box conveyor or as elements of loose material screens, which can be subjected to a load that varies over time [6-9]. This type of girders (perforated plates) can also act as mounting boards in which holes are made for various operational reasons [10-12].

Literature studies show that there are many publications undertaking an analysis of perforated plates. In general, scientists use several methods to analyze the state of stress, strains and deflection in perforated panels. Such methods are divided into three groups: analytical [13], experimental [14,15] and numerical [16-19]. Analytical methods are generally used to analyze 
very simple and uncomplicated problems. Currently, to solve problems related to plates, a new approach is most often used with the help of numerical methods using finite element methods (FEM), which allow solving complex tasks with higher accuracy. In [13], the authors propose a mathematical approach to determining internal forces in a circular perforated plate of a heat exchanger in a chemical reactor. The plate was subjected to a load that was symmetrical about the center axis of the plate and perpendicular to the center surface of the plate. The assumed mathematical algorithm provides a manner in which the state of stress in the perforated plate can be evaluated by means of analytical relations. Experimental verification of the mathematical model is presented in [14], where a methodology of the research was developed that would allow determination of stress history in perforated plates loaded centrally by concentrated force. Examples using the finite element method to analyze perforated plates are given in papers [20-22]. Using FEM, the authors [22] examined perforated panels for deflections in the center of the plate by changing the number, radius and location of the holes. Perforated plates were adopted with round holes in the number of 2 to 200, arranged in a stepped arrangement, simply supported on their four sides and subjected to a load resulting from the plate's own weight. It has been shown that the obtained deflection values can be useful in the selection of plate perforation parameters. However, the subject of research in [23-25] was the numerical analysis of the state of stress in fixed and free supported, circular axisymmetrical perforated plates loaded centrally with concentrated force or external pressure on the entire surface of the plate. In the analysed cases, stress distributions were obtained around the holes on the entire surface of the perforated plate, especially in state of stress zones. In turn, considerations related to the issue of the analysis of perforated plates included in the heat exchangers were undertaken in $[26,27,28]$.

The aim of the study reported in the present paper is to locate the zones in which maximum stresses occur in a circular axisymmetric perforated plate, free supported and loaded with concentrated force $\mathrm{P}_{\mathrm{i}}$ applied in the geometric center of the plate. Tests of stress concentration zones were performed numerically using the finite element method.

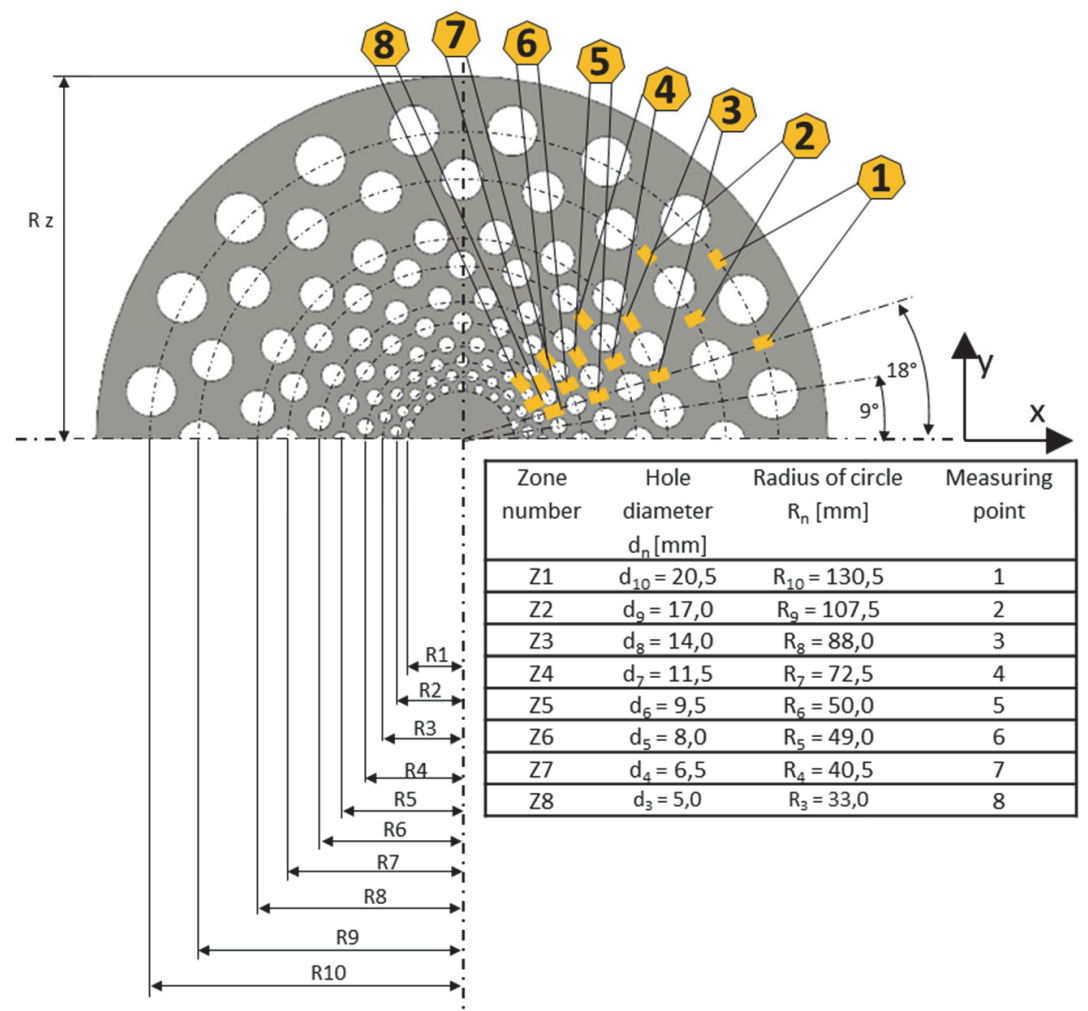

Figure 1: The arrangement of extensometers on a circular axisymmetric perforated plate - schematically (numbered 1-8) [14].

\section{EXPERIMENTAL RESEARCH}

$\mathrm{T}$

he subject for the experimental research of the state of stress was a circular axisymmetric perforated plate with dimensions: diameter $D=300 \mathrm{~mm}$, thickness, $h=5 \mathrm{~mm}$, where 200 holes with different radii were placed on the plate. These holes were arranged in 10 circles with 20 holes in each circle, as shown in Fig. 1. The plate was made 
of S235JR steel sheet with the following material parameters: Young's modulus $E=200 \mathrm{GPa}$, Poisson's ratio $v=0.3$, tensile strength $R_{m}=340-470 \mathrm{MPa}$, yield strength $R_{e}=235 \mathrm{MPa}$. The strain gauges were stuck on the previously prepared plate surface at the points shown in Fig. 1. Foil strain gauges type TF $-1 / 120, \mathrm{TF}_{\mathrm{W}}-2 / 120, \mathrm{TF}_{\mathrm{p}}-2 / 120$ were used for the measurement of strains in the perforated plate. For practical reasons, the strain gauges were placed in eight circles, meaning with radii $\mathrm{R}_{3}, \mathrm{R}_{4}, \ldots, \mathrm{R}_{10}$. Since the tested perforated plate was axially symmetric, the strain gauges were placed in the first and fourth quarter [14].

The perforated plate prepared for testing with glued strain gauges was placed on an appropriately prepared annular support centrally with respect to the loading mandrel of the universal testing machine. The diagram of mounting the plate and the place of applied load is shown in Fig. 2. The load was implemented directly using the universal testing machine mandrel, which corresponds to the case of concentrated force applied in the center of the plate. The following values of the load were assumed $P_{\mathrm{i}}: P_{1}=410 \mathrm{~N} ; P_{2}=875 \mathrm{~N} ; P_{3}=1365 \mathrm{~N} ; P_{4}=1925 \mathrm{~N} ; P_{5}=2510 \mathrm{~N}$.

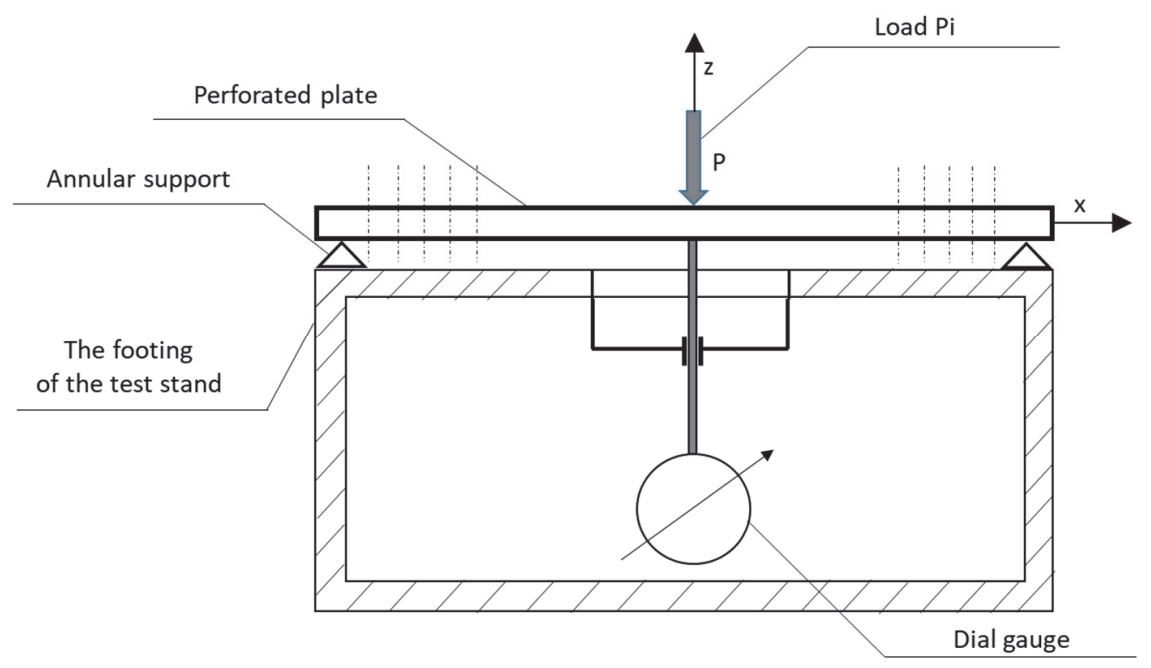

Figure 2: A scheme of the perforated plate on the test stand [14].

Knowing the radial strain values $\varepsilon_{\mathrm{r}}$ and circumferential strain values $\varepsilon_{\theta}$ in these directions calculated from the relationship:

$$
\begin{gathered}
\sigma_{1}=\frac{E}{1-v^{2}}\left(\varepsilon_{1}+v \varepsilon_{2}\right) \\
\sigma_{2}=\frac{E}{1-v^{2}}\left(\varepsilon_{2}+v \varepsilon_{1}\right)
\end{gathered}
$$

After determining the radial stress values $\sigma_{\mathrm{r}}$ and circumferential stresses values $\sigma_{\theta}$, these values were introduced into the formula for equivalent stress $\sigma_{\text {red }}$, using the von Misses hypothesis in the form [29]:

$$
\sigma_{r e d}=\sqrt{\sigma_{1}^{2}+\sigma_{2}^{2}-\sigma_{1} \sigma_{2}}
$$

\section{NUMERICAL CALCULATIONS}

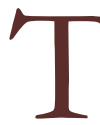

he subject for the numerical calculations of the state of stress was a circular axisymmetric perforated plate with dimensions: diameter $D=300 \mathrm{~mm}$, thickness, $h=5 \mathrm{~mm}$, where 200 holes with different radii were placed on the plate. These holes were arranged in 10 circles with 20 holes in each circle, as shown in Fig. 3. The plate was made of S235JR steel sheet with the following material parameters: Young's modulus $E=200 \mathrm{GPa}$, Poisson's ratio $\nu=0.3$, tensile strength $R_{m}=340-470 \mathrm{MPa}$, yield strength $R_{e}=235 \mathrm{MPa}$. 
The perforated plate was free supported on the entire perimeter and loaded with a concentrated force $P_{\mathrm{i}}$ applied in the geometric center of the plate (Fig. 4). Free support of the plate was realized by designing a special annular support. The perforated plate was placed on the annular support and contact between the plate and the support was used in the form of a low friction value. The following values of the load were assumed $P_{\mathrm{i}}: P_{1}=410 \mathrm{~N} ; P_{2}=875 \mathrm{~N} ; P_{3}=1365 \mathrm{~N} ; P_{4}=1925 \mathrm{~N}$; $P_{5}=2510 \mathrm{~N}$. To determine the areas of maximum stress in a plate ten measuring zones, i.e. from Z1 to Z10 (Fig. 3), were placed on the circular axisymmetric perforated plate.

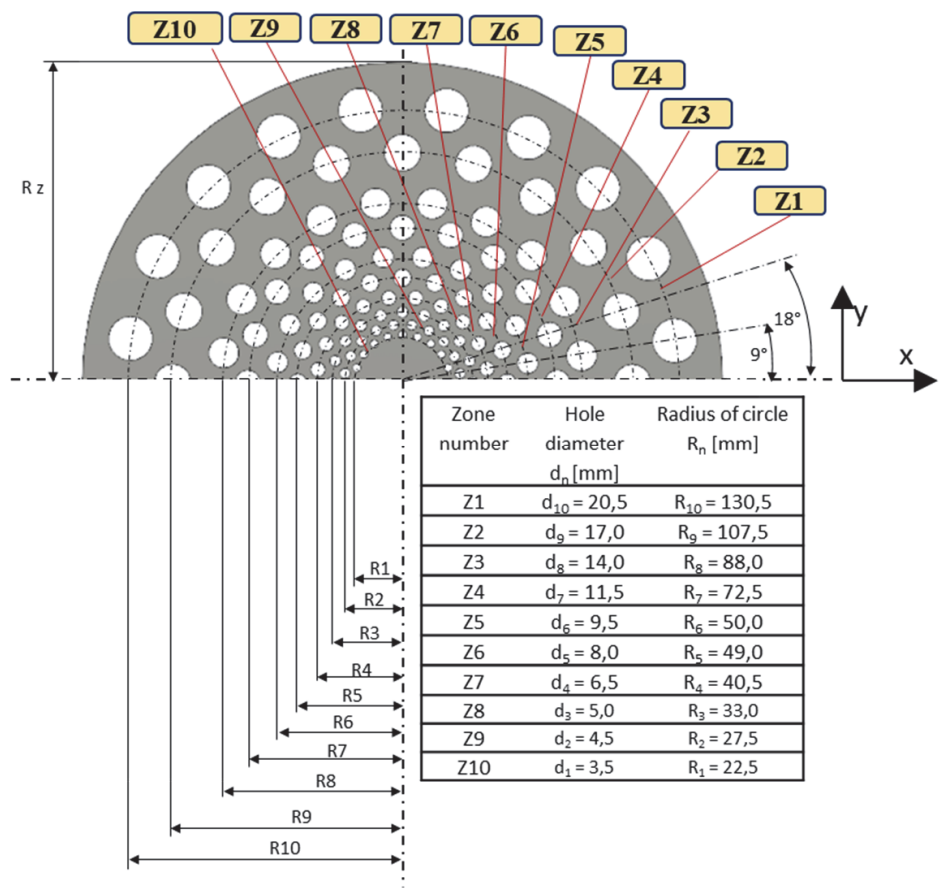

Figure 3: Model of perforated plate with ten measuring zones, i.e. from Z1 to Z10 [14].

Geometry

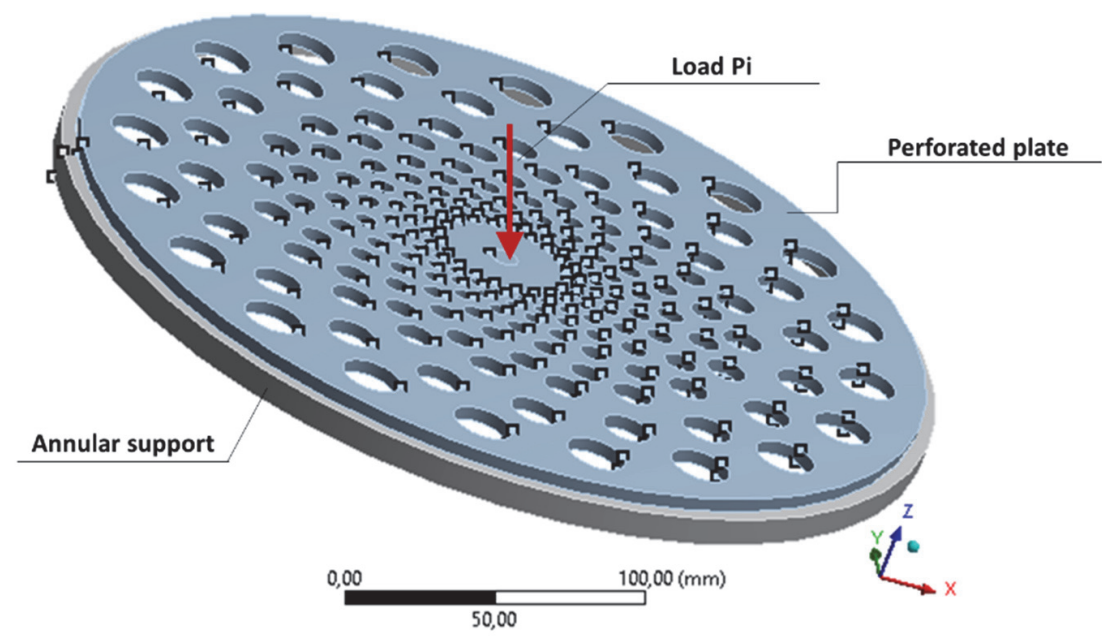

Figure 4: A circular axisymmetric perforated plate loaded with concentrated force $P_{i}$ applied in the geometric center of the plate and free supported over the entire perimeter.

Numerical calculations were carried out using the ANSYS program [30]. ANSYS is a program for numerical calculations using the finite element method (FEM). It allows solving complex tasks with high accuracy. ANSYS uses a range of advanced 
and universal technologies that enable quick, efficient and simple preparation of the calculation model. Numerical calculations were carried out in a linearly elastic range.

The solid plate was modelled using cubic spatial finite elements (3D) with square sides containing twenty nodes (eight nodes in the corners and twelve on the edges of the element sides), i.e. W20, described by a square shape function (Fig. 3). The computational model contained the total number of finite elements 615202, while the total number of nodes was 2817069. The solid plate had 7 layers of finite elements.

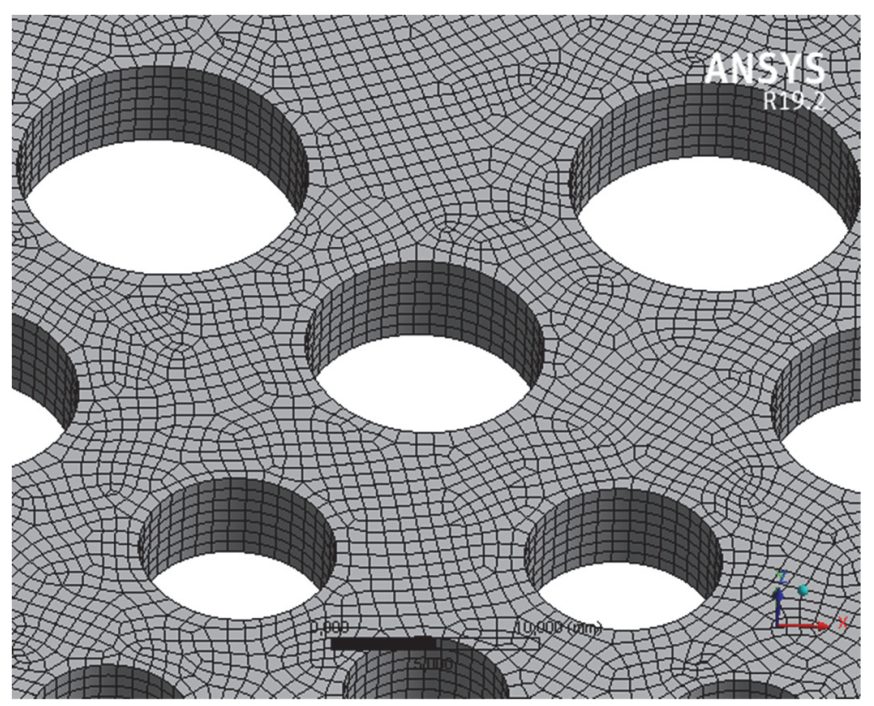

Figure 5: Division of the plate into finite elements.

For example, in Fig. 6, the distribution of equivalent stresses $\sigma_{\text {red }}$ is given, calculated according to the von Misses hypothesis in a circular axisymmetrical perforated plate, free supported and loaded with concentrated force $P_{i}$ applied in the geometric center of the plate with the value $P_{5}=2510 \mathrm{~N}$. However, the location of stress concentration zones in the tested plate is shown in Fig. 7. The figure illustrates the distribution of equivalent stresses given in $\mathrm{MPa}$ in ten measuring zones (Fig. 3). Points T1 to T10 define the values of equivalent stresses obtained numerically at control measuring points, and P1 to P10 are points that identify the maximum numerical values of stress. In square brackets, the values of three coordinates, i.e. $x$, y, z coordinates, are given (Fig. 7).

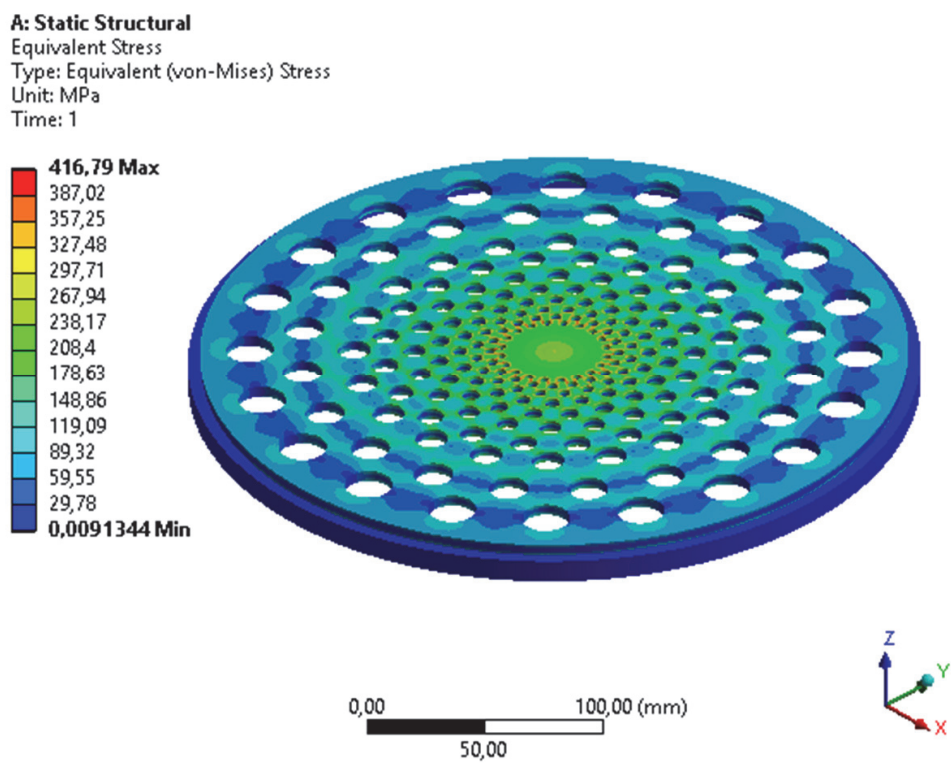

Figure 6: Distribution of equivalent (von Mises) stress $\sigma_{\text {red }}$ given in $\mathrm{MPa}$ for the circular axisymmetric perforated plate free supported and loaded with concentrated force $P_{i}$ applied in the geometric center of the plate with the value $P_{5}=2510 \mathrm{~N}, \sigma_{\mathrm{red} \max }=416.79 \mathrm{MPa}$. 

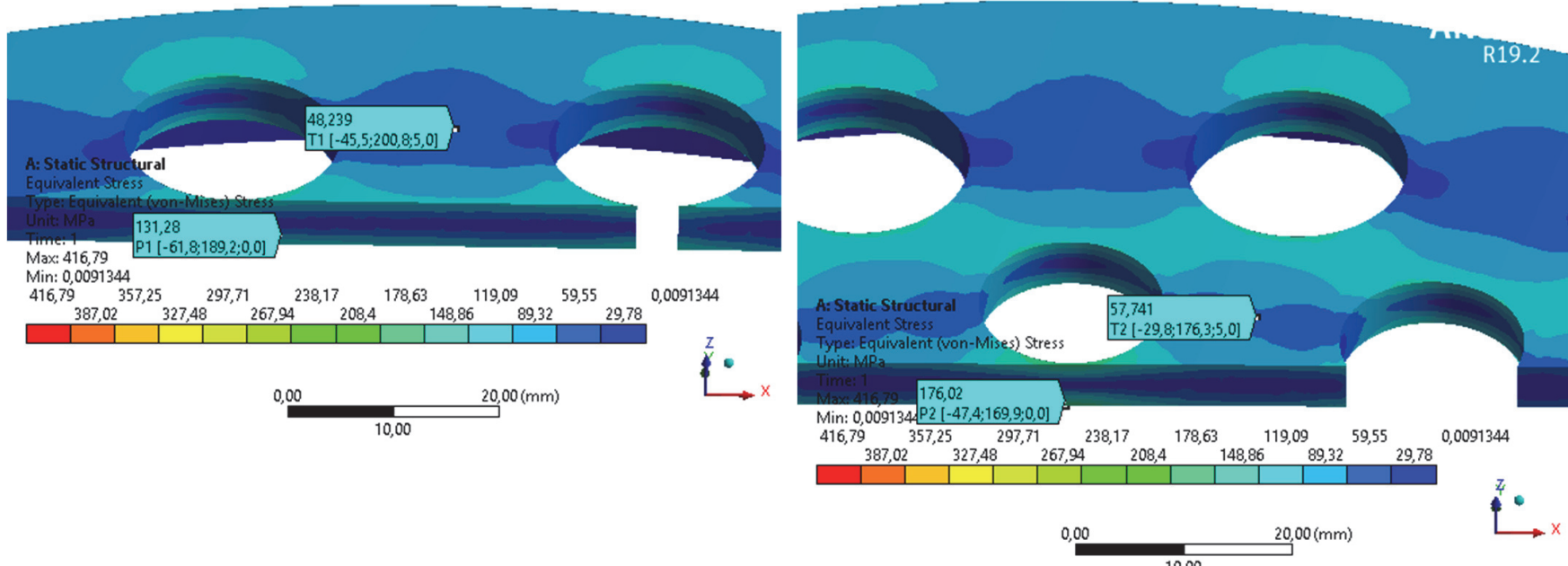

1) zone Z1: $\sigma_{\text {red } \max }=131.28 \mathrm{MPa}$

2) zone $\mathrm{Z} 2: \sigma_{\text {red } \max }=176.02 \mathrm{MPa}$
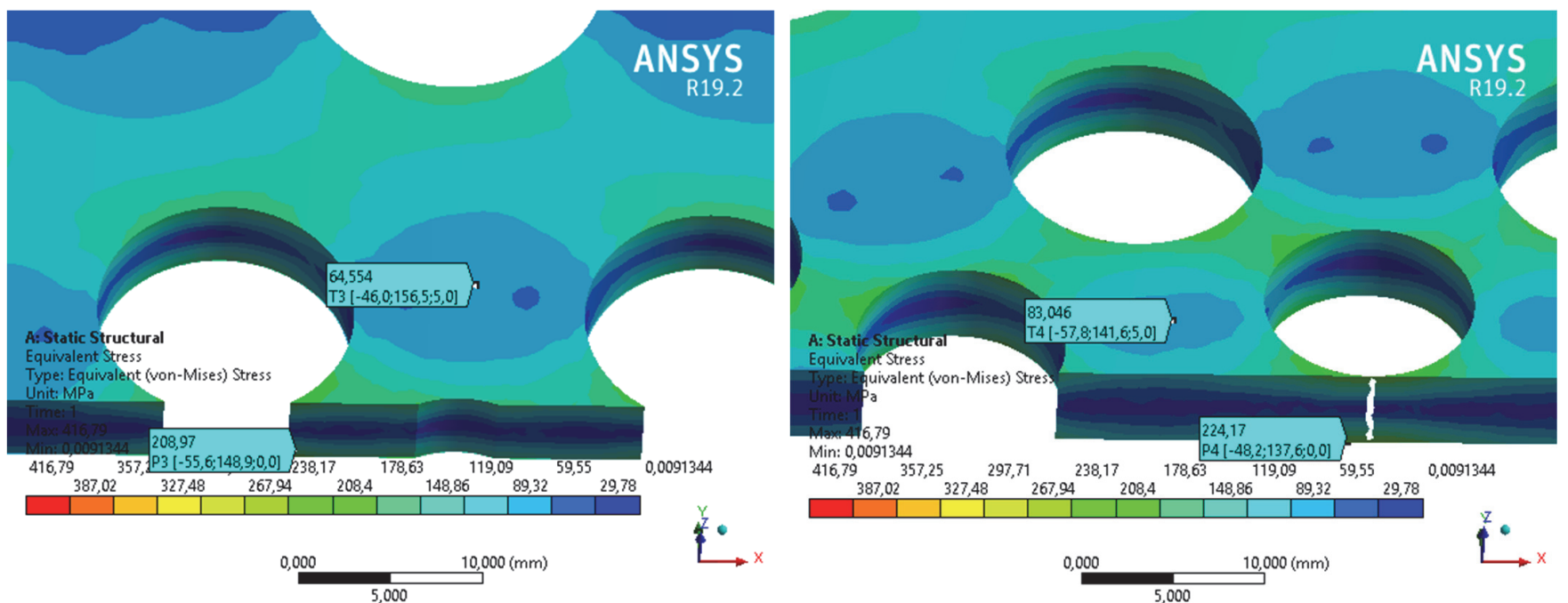

3) zone $\mathrm{Z3:} \sigma_{\text {red } \max }=208.97 \mathrm{MPa}$

4) zone $Z 4: \sigma_{\text {red } \max }=224.17 \mathrm{MPa}$

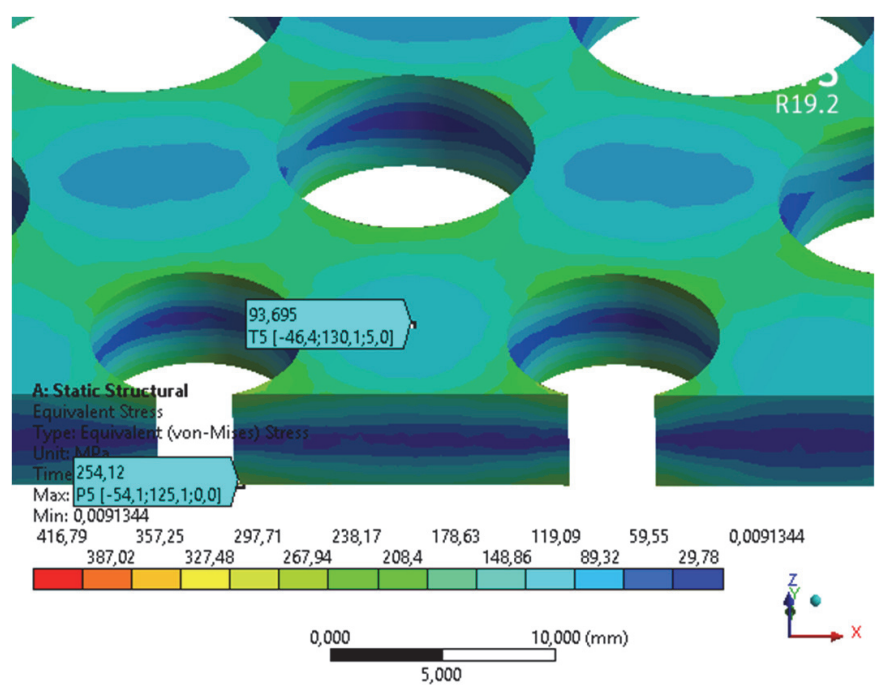

5) zone Z5: $\sigma_{\text {red } \max }=254.12 \mathrm{MPa}$

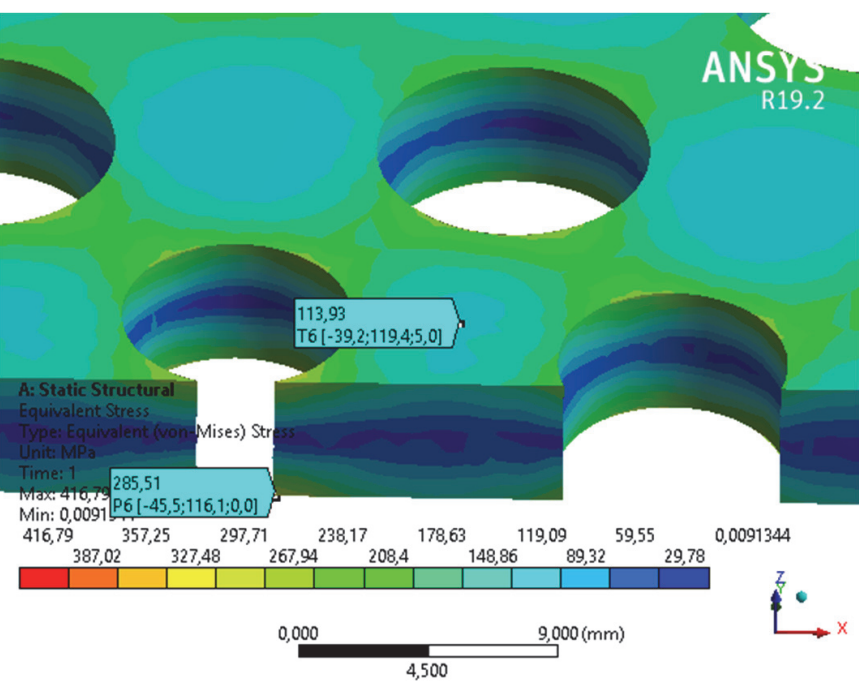

6) zone Z6: $\sigma_{\text {red } \max }=285.51 \mathrm{MPa}$ 


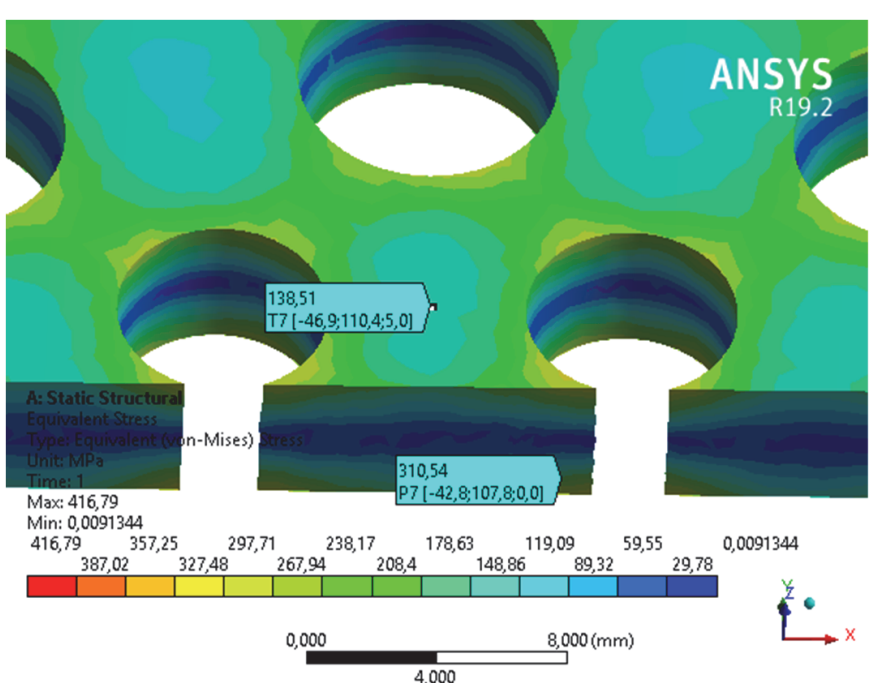

7) zone Z7: $\sigma_{\text {red } \max }=310.54 \mathrm{MPa}$

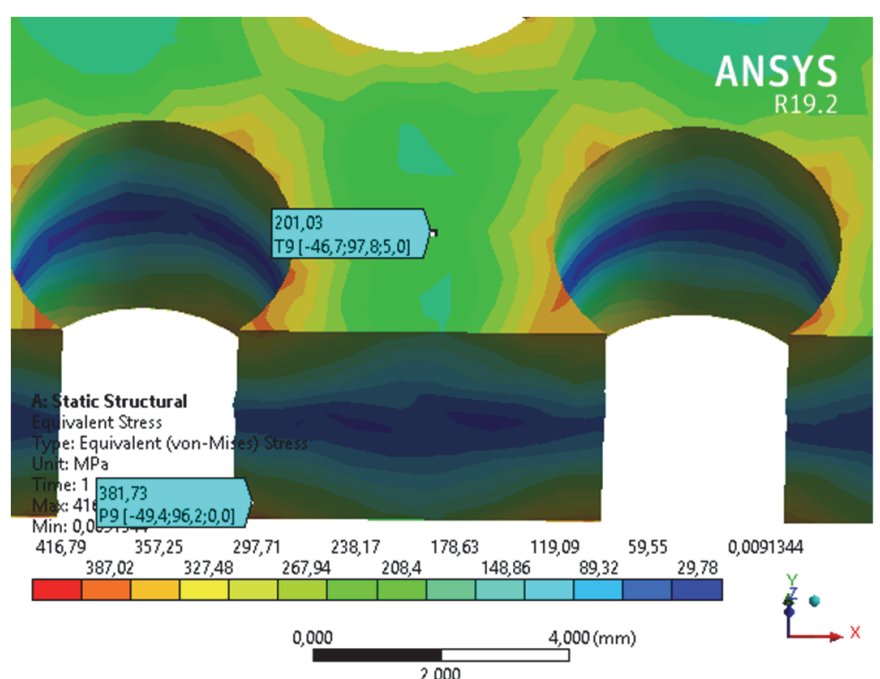

9) zone Z9: $\sigma_{\text {red } \max }=381.73 \mathrm{MPa}$

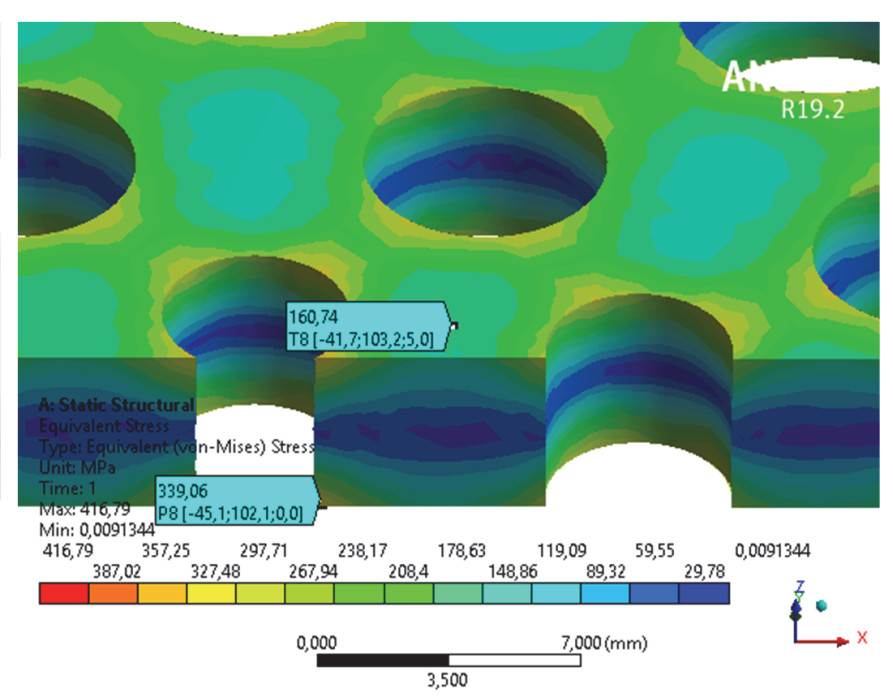

8) zone Z8: $\sigma_{\text {red max }}=339.06 \mathrm{MPa}$

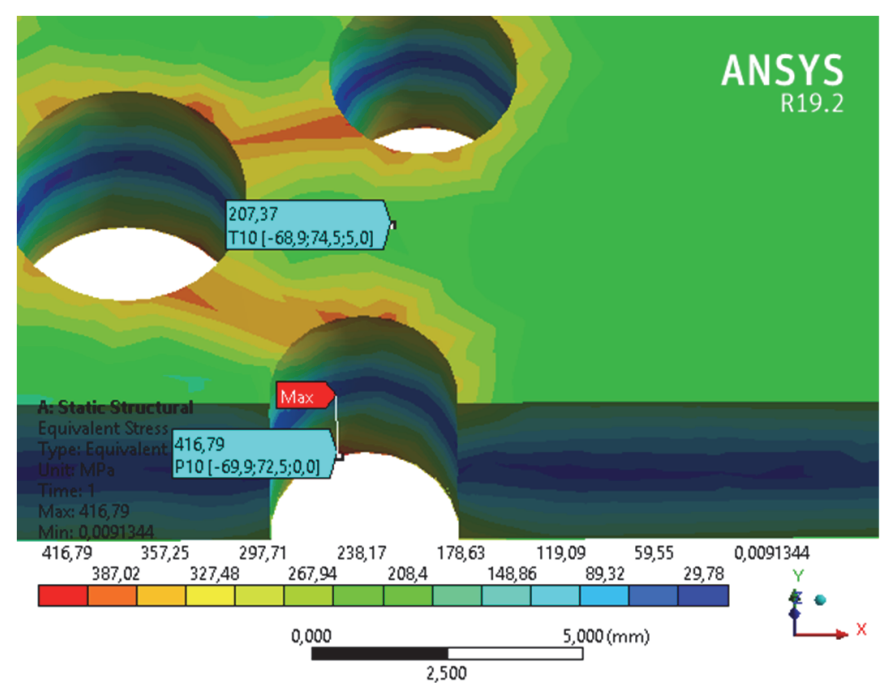

10) zone Z10: $\sigma_{\text {red } \max }=416.79 \mathrm{MPa}$

Figure 7. Equivalent (von Mises) stress zones $\sigma_{\text {red }}$ given in MPa for the circular axisymmetric perforated plate free supported and loaded with concentrated force $P_{i}$ applied in the geometric center of the plate with the value $P_{5}=2510 \mathrm{~N}$.

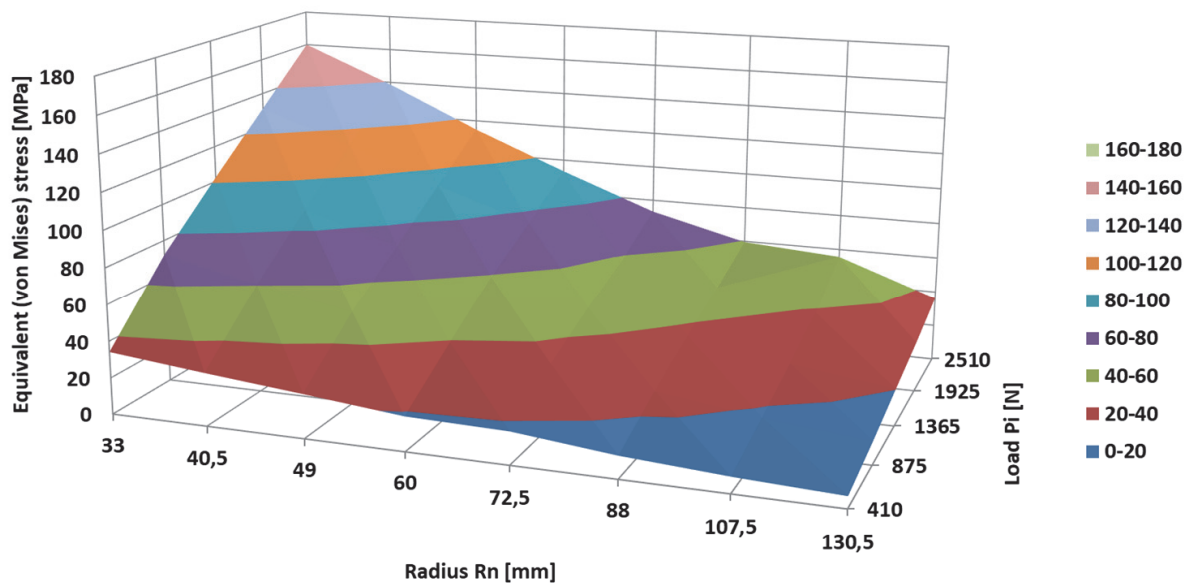

Figure 8: The course of the equivalent stresses changes using the von Mises hypothesis for a circular axisymmetric perforated plate, free supported and loaded with concentrated force $P_{i}$ applied in the geometric center of the plate, experimentally determined. 


\section{CONCLUSIONS}

$\mathrm{B}$ ased on numerical calculations using the finite element method (FEM) and experimental research, the results that were obtained could be compared. The Figs. 8 - 10 present the values of the equivalent (von Mises) stresses $\sigma_{\text {red }}$ in the stress concentrated zones for a circular axisymmetric perforated plate, free supported and loaded with concentrated force $P_{i}$ applied in the geometric center of the plate, numerically and experimentally determined in eight measuring points and the difference between the results obtained methods $\delta \sigma$.

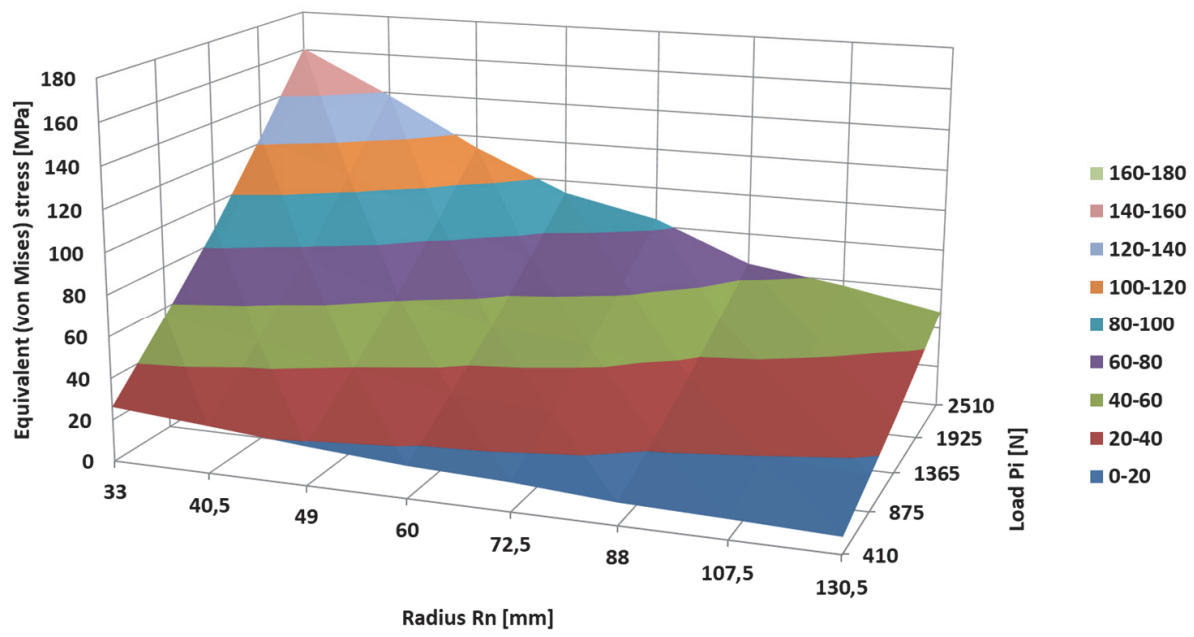

Figure 9: The course of equivalent stresses changes using the von Mises hypothesis for a circular axisymmetric perforated plate, free supported and loaded with concentrated force $P_{i}$ applied in the geometric center of the plate, numerically determined.

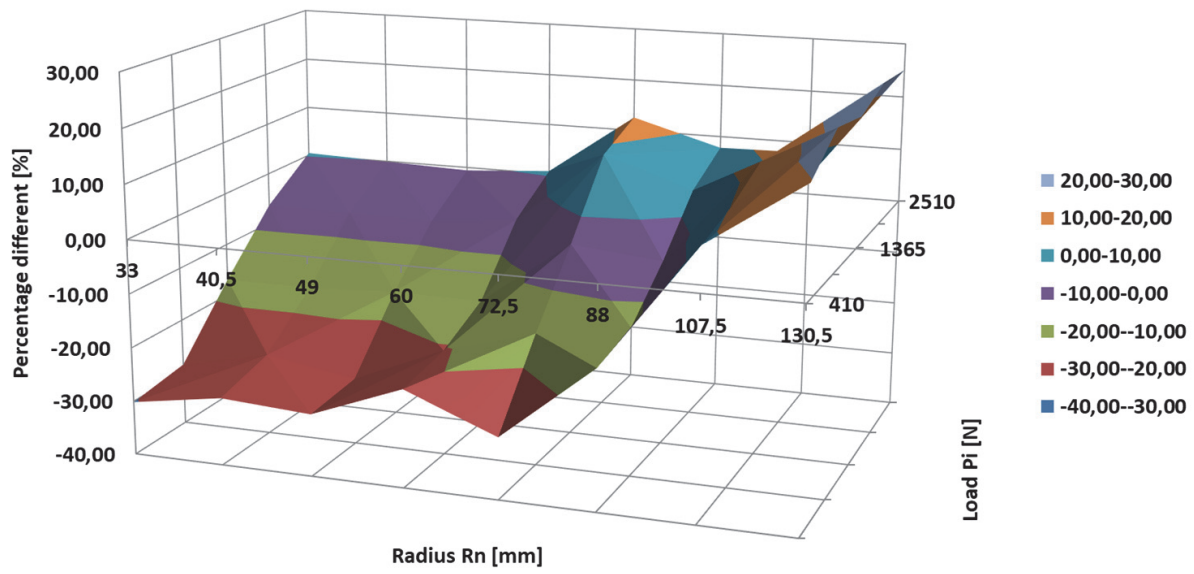

Figure 10: Percentage difference in equivalent stress variations $\delta \sigma_{\text {red }}$ according to von Mises hypothesis for a circular axisymmetric perforated plate, free supported and loaded with concentrated force $P_{i}$ applied in the geometric center of the plate, numerically and experimentally determined.

The results of calculations indicate that the highest value of equivalent (von Mises) stress $\sigma_{\text {red }}$ Occurred when the perforated plate was loaded with concentrated force Pi applied in the geometrical center of the plate with the value $\mathrm{P}_{5}=2510 \mathrm{~N}$, both in the case of experimental research and numerical calculations. For example, in second zone Z2, the equivalent (von Mises) stress determined experimentally was equal to $\sigma_{\text {red }}^{\mathrm{e}}=55.62 \mathrm{MPa}$, and the calculated numerically was equal to $\sigma^{\mathrm{n}}$ red $=57.54$ $\mathrm{MPa}$ (Fig. 7, zone 2). The relative difference in this case was 3.34\%. In the Z8 eighth zone, the equivalent (von Mises) stress determined experimentally was equal to $\sigma_{\text {red }}=160.03 \mathrm{MPa}$, and the numerical calculated was equal to $\sigma_{\text {red }}=160.74 \mathrm{MPa}$ (Fig. 7, zone 8). The relative difference in this case was $0.44 \%$. The state of stress in the perforated plate free supported on the entire perimeter and loaded with a concentrated force $P_{\mathrm{i}}$ applied in the geometric center of the plate determined by the finite element method (FEM) of the ANSYS program, can be considered sufficiently accurate for engineering calculations. 
The diameter of the perforation hole in the perforated plate has a significant impact on the stress distribution in the plate in which such geometric discontinuity occurs. The most hazardous place in a circular axisymmetric perforated plate, free supported and loaded with concentrated force $P_{i}$ applied in the geometric center of the plate with the highest stress concentration is located in zone Z10 with the hole radius $d_{1}=3.5 \mathrm{~mm}$ and the radius of the circle on which the hole $R_{1}=$ $22.5 \mathrm{~mm}$ is located, the equivalent (von Mises) stress is $\sigma_{\text {red } \max }=416.79 \mathrm{MPa}$ (point with the coordinates x,y,z [mm], i.e.. P10 [-69.9; 72.5; 0.0]), (Fig. 7, zone Z10). Maximum relative disaggregations expressed in terms of the values of equivalent (von Mises) stresses $\sigma_{\text {red }}$ obtained by the numerical method using the finite element method and the experimental method, in a circular axisymmetric perforated plate, with free edge support, did not exceed $31 \%$ in the present research. Significant values of equivalent (von Mises) stress $\sigma_{\text {red }}$ form the common reason for the development of microcracks in the area of the perforation hole. In the case of variable (fatigue) loads, microcracks start to develop and, as a consequence, they may cause the failure of a machine element or in a part in which the perforated element is located. In connection with the above, it is very important to determine the value and location of stress concentration in machine components representing the reasons responsible for their occurrence.

\section{REFERENCES}

[1] Chudzik, A. and Świniarski, J. (2004). Effect of changes in the thickness of a perforated plate of the heat exchanger on its structural stability. Journal of Theoretical and Applied Mechanics, 42(2), pp. 325-334.

[2] Achtelik, H., Gasiak, G. and Grzelak, J. (1997). Wykonanie obliczeń wytrzymałości den tłoczonych i płyt sitowych wymienników ciepła wnętrza reaktora syntezy amoniaku dla Z.A. Puławy. Praca NB - 48/97, wykonano na zlecenie APC - METCHEM sp. z.o.o. w Opolu pismem L.dz. /TK - 420/509/97 z dnia 04.07.1997 (in Polish).

[3] Sharma, S., Singh, R. and Kashiv, M. (2015). Finite element analysis of heat exchanger. International Journal of Modern Engineering Research, 5(2), pp. 62-65.

[4] Vishwas, P. T., Jayant, S. and Patil, V. (2014). Finite element analysis based structural analysis of stacked heat exchanger. Journal of Mechanical and Civil Engineering, 11(4), pp. 65-69.

[5] Azelmad, E., Salmi, A., El Kennassi, E. and Bousshine, L. (2018). Elastoplastic Behavioranalysis of Clamped Circular Perforated Thin Plates. IOSR Journal of Mechanical and Civil Engineering (IOSR-JMCE), 15(2), pp. 23-37.

[6] Achtelik, H., Gasiak, G. and Sojka, M. (2006), Topografia trwałości zmęczeniowej kwadratowych płyt perforowanych przy obciążeniach cyklicznych. XXI Sympozjon PKM, Bydgoszcz - Pieczyska, pp. 13-22 (in Polish).

[7] Selkar, A. R. and Tambe, P. D. (2015). Free vibration analysis of perforated plate. International Engineering Research Journal, pp. 1412-1420.

[8] Patil, D. C., Gawade, S. S. and Kiran M. (2007). Dynamic response analysis of rectangular perforated plates with varying size of circular perforation holes. 14 $4^{\text {th }}$ International Congress on Sound Vibration, 9 - 12 July, 2007, Cairns Australia, pp. 1-6.

[9] Young, M. J. and Jo, J. C. (2006). Equivalent material properties of perforated plate with triangular or square penetration pattern for dynamic analysis. Nuclear Engineering and Technology, 38(7), pp. 689-696.

[10] Paik, J. (2008). Ultimate strength of perforated steel plates under combined biaxial compression and edge shear loads. Thin-walled structures, 46, pp. 207-213.

[11] Lee, Y.-CH. and Chen F.-K. (2000). Yield criterion for a perforated sheet with a uniform triangular pattern of round holes and a low ligament ratio. Journal of Materials Processing Technology, 103, pp. 353-361.

[12] Kang, J. H. (2014). Exact solutions of stresses, strains, and displacements of a perforated rectangular plate by a central circular hole subjected to linearly varying inplane normal stresses on two opposite edges. International Journal of Mechanical Sciences, 84, pp. 18-24.

[13] Achtelik, H., Gasiak, G. and Grzelak, J. (2008). Strength tests of axially symmetric perforated plates for chemical reactors: Part 1 - The simulation of stress state. International Journal of Pressure Vessels and Piping, 85, pp. 248-256.

[14] Achtelik, H., Gasiak, G. and Grzelak, J. (2008). Strength tests of axially symmetric perforated plates for chemical reactors: Part 2 - Experiments. International Journal of Pressure Vessels and Piping, 85, pp. 257-264.

[15] Thorwat, P. J. and Marne, R. (2015). Stress analysis of a perforated plate through experimental and computational methods. International Engineering Research Journal, 1(6), pp. 482-487.

[16] Andh, U. Chavan, S. Kulkarni, S. and Khurd, S. (2016). Stress analysis of perforated plates under uniaxial compression using FEA and photoelasticity. International Research Journal of Engineering and Technology, 3(11), pp. $239-244$. 
[17] Andh, U. Chavan, S. and Kulkarni, S. (2017). Stress analysis of perforated plates under uniaxial compression using experimentation and finite element analysis. International Journal of Current Engineering and Technology, 7(2), pp. 431-437.

[18] Baik, S. C., Oh, K. H. and Lee, D. N. (1996). Analysis of the deformation of a perforated sheet under uniaxial tension, Journal Materials Processing Technolgy, 58, pp. 139-144.

[19] Albayrak, U. and Saraçoğlu, M. H. (2011). Analyzing of thin square plates with multiple circular holes. Proceedings of the International Symposium on Advances in Applied Mechanics and Modern Information Technology (ISAAM\&MIT"11), pp. 79-83.

[20] Konieczny, M. (2019). Numeryczna analiza stanu naprężenia w kołowosymetrycznej płycie z otworem centralntm przy dwóch wariantach obciążenia. Zagadnienia Aktualnie Poruszane przez Młodych Naukowców 14 Kraków (in Polish).

[21] Pawar, P. and Ballav, R. and Kumar, A. (2016). Finite element method analysis of rectangular plate with circular hole using ANSYS. International Journal Chemical Scientific, 14(4), pp. 2787 - 2797.

[22] Saraçoğlu, M. H. and Albayrak, U. (2016). Linear static analysis of perforated plates with round and staggered holes under their self-weights. Research of Engineering Structures and Materials, 2(1), pp. 39-47.

[23] Konieczny, M., Achtelik, H. and Gasiak, G. (2019). Research of maximum stresses zones in circular perforated plates made of S235JR steel loaded with concentrated force. Inżynieria Materiałowa - Materials Engineering, 2(228), pp. 3946.

[24] Konieczny, M. and Gasiak, G. (2019). Lokalizacja stref spiętrzenia naprężeń w płycie sitowej wymiennika ciepła. Modelowanie Inżynierskie, 70, ss. 49-55 (in Polish).

[25] Konieczny, M., and Gasiak, G. (2019). Badanie wpływu zamocowania kołowej płyty perforowanej na koncentracje naprężenia w warunkach działania ciśnienia hydrostatycznego. Zeszyty Naukowe Politechniki Rzeszowskiej - Scientific Letters of Rzeszow University of Technology, 299(1-2), pp. 41-52 (in Polish).

[26] Azelmad, E., Salmi, A. and El Kennassi, E., Bousshine, L. (2018). Elastoplastic Behavioranalysis of Clamped Circular Perforated Thin Plates. IOSR Journal of Mechanical and Civil Engineering (IOSR-JMCE), 15(2), pp. 23-37.

[27] Chudzik, A. (2007). Optymalizacja konstrukcji wymiennika ciepła. Biuletyn WAT, LV), ss. 1-6.

[28] Niezgodzinski, M. E. (1973). Obliczenie den sitowych zbiorników ciśnieniowych. Przegląd Mechaniczny, 3 (in Polish).

[29] Jakubowicz, A. and Orłoś, Z. (1984). Wytrzymałość materiałów, WNT, Warszawa, s. 636 (in Polish).

[30] www.mesco.com.pl 15.04.2017. 